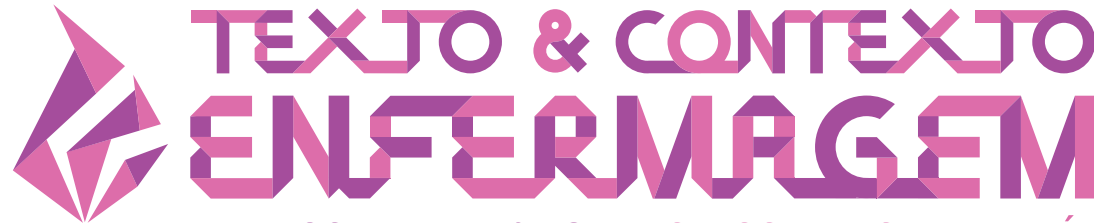

\section{PERCEPTION OF HARMS AND BENEFITS ASSOCIATED WITH MARIJUANA USE AMONG ADOLESCENTS IN ST KITTS- NEVIS - CARIBE}

Gaile Gray-Phillip ${ }^{1}$ (D) Bruna Brands ${ }^{2,3}$

${ }^{1}$ Government of St. Kitts and Nevis, Ministry of Sustainable Development. Basseterre, Kitts and Nevis. ${ }^{2}$ University of Toronto. Toronto, Canada. ${ }^{3}$ Centre for Addiction and Mental Health. Toronto, Canada.

\begin{abstract}
Objective: this investigation examined adolescents' perception of the harms and benefits of marijuana use and how regulatory changes may affect their intent to use marijuana.

Method: this cross-sectional survey gathered data from 26815 to 17 years old students who were enrolled in public secondary schools in St Kitts-Nevis - Caribe.

Results: forty five percent of the students perceive that there is no risk if marijuana is smoked once or twice. One out of every 4 students felt that there is great risk if marijuana is used regularly. About half of the students felt that marijuana helps persons their age to cope with emotional difficulties. Students who have used marijuana have a low perception of the risks associated with marijuana use and are seven times more likely to continue using marijuana, if it were legal and they were 18 years of age.

Conclusion: most of the students perceive that there is no personal harm associated with smoking marijuana. Students are not sure whether the benefits of using marijuana are greater than the risks. A noticeable proportion of students were unsure of the harms and benefits associated with marijuana use. It is recommended that suitable educational and preventative programmes be implemented in schools.
\end{abstract}

DESCRIPTORS: Marijuana use. Adolescents. Risk. Marijuana smoking. Drugs. 


\section{PERCEPÇÃO DE DANOS E BENEFÍCIOS ASSOCIADOS AO USO DE MACONHA ENTRE ADOLESCENTES EM ST KITTS-NEVIS-CARIBE}

\section{RESUMO}

Objetivo: esta investigação analisou a percepção dos adolescentes sobre os danos e benefícios do uso de maconha e como as mudanças regulatórias podem afetar sua intenção de usar maconha.

Método: este estudo de levantamento transversal reuniu dados de 268 alunos de 15 a 17 anos matriculados em escolas públicas de ensino médio em St. Kitts-Nevis - Caribe.

Resultados: quarenta e cinco por cento dos estudantes afirmaram que não há risco se a maconha for consumida uma ou duas vezes. Um em cada quatro estudantes sentiu que há um grande risco se a maconha for usada regularmente. Cerca de metade dos alunos relatou que a maconha ajuda as pessoas da sua idade a lidar com dificuldades emocionais. Os estudantes que usaram maconha têm uma baixa percepção dos riscos associados ao uso de maconha e são sete vezes mais propensos a continuar usando maconha, se fosse legalizada e se tivessem 18 anos de idade.

Conclusão: a maioria dos estudantes percebe que não há danos pessoais associados ao consumo de maconha. Os estudantes não têm certeza se os benefícios do uso da maconha são maiores que os riscos. Uma proporção notável de estudantes não tinha certeza dos danos e benefícios associados ao uso de maconha. Recomenda-se que sejam implementados programas educativos e preventivos adequados nas escolas.

DESCRITORES: Uso de maconha. Adolescentes. Risco. Fumar maconha. Drogas.

\section{PERCEPCIÓN DE DAÑOS Y BENEFICIOS RELACIONADOS AL USO DE LA MARIHUANA ENTRE ADOLESCENTES EN ST KITTS-NEVIS EN EL CARIBE}

\section{RESUMEN}

Objetivo: esta investigación analizó las percepciones de los adolescentes sobre los daños y beneficios del uso de la marihuana y cómo los cambios regulatorios pueden afectar su intención de consumirla.

Método: este estudio transversal recolectó datos de 268 estudiantes de 15 a 17 años inscritos en escuelas secundarias públicas en St. Kitts-Nevis en el Caribe.

Resultados: el $45 \%$ de los estudiantes dijeron que no había riesgo si la marihuana se consumía una o dos veces. Uno de cada cuatro estudiantes sintió que existe un gran riesgo si la marihuana se usa de forma regular. Alrededor de la mitad de los estudiantes informó que la marihuana ayuda a las personas de su edad a enfrentar dificultades emocionales. Los estudiantes que consumieron marihuana tienen una baja percepción de los riesgos asociados al uso de la misma y siete veces más probabilidades de seguir consumiendo marihuana si esta estuviera legalizada y si tuvieran 18 años.

Conclusión: la mayoría de los estudiantes se da cuenta de que no hay lesiones personales asociadas con el consumo de la marihuana. Los estudiantes no están seguros de si los beneficios del consumo de la marihuana son mayores que los riesgos. Un número notable de los estudiantes no estaba seguro de los daños y beneficios asociados al uso de la marihuana. Se recomienda que se implementen programas educativos y preventivos apropiados en las escuelas.

DESCRIPTORES: Uso de la marihuana. Adolescentes. Riesgos. Fumar marihuana. Drogas. 


\section{INTRODUCTION}

In June of 2016, the Caribbean Community (CARICOM) Regional Commission on Marijuana held its' first national consultations on the use of marijuana for medicinal purposes. According to CANA News, ${ }^{1}$ the objective of the Commission is to examine the legal, economic, health and social issues of marijuana use in the Caribbean region. In addition, the Commission aims to determine whether the current drug classification for marijuana, Schedule II, as classified by the United Nations Convention on Psychotropic Substances, should be changed to make marijuana more accessible for a variety of uses.

In 2015, Jamaica decriminalized marijuana, thereby allowing individuals to possess 2 ounces or less of marijuana, for personal, medicinal and religious use, without being arrested, charged or taken to court. ${ }^{2}$ In other Caribbean countries, activists have been calling for the decriminalization of marijuana. ${ }^{3-4}$

In St. Kitts-Nevis, the National Council on Drug Abuse Prevention hosted a one-day national discussion on the decriminalization of marijuana in the federation. ${ }^{5}$ According to the St. Kitts-Nevis National Drug Council's report, ${ }^{6}$ representatives from health, education, security/policing, social protection, youth and religion and community values contributed to the discussion. The different sectors hypothesized the pros and cons if marijuana were to be decriminalized in the federation. The pros identified by the youth group included using marijuana to treat Attention Deficit Hyperactivity Disorder and the ability to be able to produce 'pure' marijuana for use. The cons included increased psychiatric issues among youths and decrease in the ability to control the use of marijuana.

The Organization of American States ${ }^{7}$ purports that easier access to marijuana and decreasing perception of risk related to marijuana use contribute to an increased trend in marijuana consumption among adolescents. According to the CICAD Secondary School Drug Prevalence Survey, ${ }^{8}$ which was conducted in 2013 in St. Kitts and Nevis, half of the students, between the ages of 13 to 17, perceive that frequent consumption of marijuana is very harmful to one's health. Sixteen percent of the students stated that marijuana is not harmful if used sometimes. The $2013 \mathrm{CICAD}$ survey also found that there was a $10 \%$ increase in the lifetime prevalence of marijuana use among students, when compared with the results of the 2006 CICAD survey. It is against this background of discussions on regulatory changes and increasing marijuana use among adolescents that the need to conduct this investigation emerged.

This study sought to examine 15-17 year old adolescents' perception of the harms and benefits of marijuana use and how regulatory changes may affect their intent to use marijuana. The research questions are as follows: 1) How do students' perceive the risks associated with marijuana use? 2) How do students' perceive the benefits associated with marijuana use? 3) Are students who have tried marijuana less likely to perceive marijuana use as harmful? And 4) How do students' perceive regulatory changes affecting their intention to use marijuana?

\section{METHOD}

This investigation forms part of a multicentric study aimed at investigating the perceptions of harms and benefits associated with marijuana use among adolescents within Belize, Brazil, Chile, Colombia, Dominican Republic, Jamaica, Mexico, St. Kitts and Nevis, and Trinidad and Tobago. The study being presented within this paper focuses on a cross-sectional survey of 15-17 year old students, who attend public secondary school, in St. Kitts-Nevis. Students in Forms 4 and 5 (Grades 10 and 11), between the ages of 15-17, were targeted. Convenience sampling was used to select three public secondary schools, in St Kitts, from which the sample was selected. The inclusion criteria were: 15 to 17 years of age, enrolled in a public secondary school, able to read and write in English 
without assistance and gave consent to participate in the survey. Five hundred and sixty-two (562) students fitted the inclusion criteria, of which 313 gave consent to participate in the survey. After data cleaning, the sample comprised of 268 students. Data was gathered between March and April of 2015.

A questionnaire consisting of 23 questions was used to gather the data. The questionnaire was developed by adapting relevant items from the following instruments: a) Inter-American Drug Use Data System (SIDUC) Secondary Students School Survey; ${ }^{9}$ b) Monitoring The Future (MTF); ${ }^{10}$ and, c) the Benthin Risk Perception Measure. ${ }^{11}$ Demographic information, prevalence, frequency of smoking marijuana and age of onset were assessed by adapting relevant items from the Inter-American Drug Use Data System Secondary School Student Survey. These questions collected data on respondents' sex, age, grade, marijuana use (lifetime, past-12 months and past 30 days), frequency of smoking marijuana and age of onset. Students' perception of the harms, associated with experimental and frequent marijuana use, were assessed by adapting three relevant items from the Monitoring The Future instrument. Eleven questions from the The Benthin Risk Perception Measure were slightly modified and used to gather data on the respondents' perceptions on the harms and benefits of smoking marijuana. The Benthin Risk Perception Measure uses a seven-point scale to assess the perceived risks and benefits of various behaviours. One item gathered data on respondents' intent to use marijuana within the context of regulatory changes. The developed instrument was pretested using seven students, in the 15 to 17 year group, who were not enrolled in any of the schools selected for this survey. The pretest showed that the language was clear and the questions were explicit.

Before the data gathering process, a letter was sent to parents and students informing them of the survey and soliciting students' participation. For the administration of the questionnaire, students were reminded of the objectives of the survey, that their participation is voluntary and that they could stop at any time. The students were also informed that the survey is anonymous and that confidentiality of their responses will be respected within the fullest extent possible by law. The main researcher, along with Form room teachers and guidance counsellors, distributed the questionnaire and monitored the activity. Students were not required to write their names on the questionnaire. Completed questionnaires were immediately placed in a large envelope, sealed and handed to the main researcher.

The data gathered were entered into the software Statistical Package for the Social Sciences (SPSS) Version 21 for summary and analysis. The accuracy of the data entry was validated by randomly cross-checking $20 \%$ of questionnaires against the database. Descriptive and inferential statistics were used to analyse the data. An overall average score of risk based on the student's perception of harms and benefits was calculated for each student. A higher score reflects high risk; ${ }^{12}$ that is, lower perception of harm and a higher perception of benefits related to marijuana use. Chi-square $\left(c^{2}\right)$ tests were conducted to explore relationships between various variables while $t$-tests were used to determine whether there were statistically significant differences between the perceived risks of students who have tried marijuana and those who have not tried marijuana.

\section{RESULTS}

The majority $(56 \%)$ of the students who participated in the survey were females. The mean age of students was $15.74(\mathrm{SD}=0.74)$. Table 1 summarises the demographic characteristics of the students surveyed. 
Table 1 - Distribution of demographic characteristics of the students surveyed, St. Kitts-Nevis, 2015

\begin{tabular}{lccc}
\hline Variable & Category & $\mathbf{n}$ & \% \\
\hline Gender & Male & 118 & 44 \\
& Female & 150 & 56 \\
Age & 15 & 118 & 44 \\
& 16 & 102 & 38 \\
\multirow{3}{*}{ Form (Grade) } & 17 & 48 & 18 \\
& $4(11)$ & 197 & 74 \\
& $5(12)$ & 71 & 26 \\
\hline
\end{tabular}

Approximately $39 \%$ of the students surveyed stated that some of their friends use marijuana. Overall, $42 \%$ of the students either did not know if their friends use marijuana or stated that none of their friends use marijuana. Four percent reported that all of their friends use marijuana. A similar proportion of females (57\%) and males $(58 \%)$ indicated that they have friends who use marijuana.

With regard to marijuana use, approximately 3 out of every 10 students indicated that they have smoked marijuana. Approximately $40 \%$ of the males and $24 \%$ of the females indicated that they have smoked marijuana at least once in their lifetime. Approximately $30 \%$ of the 15 -year-olds indicated that they have smoked marijuana while $31.7 \%$ and $29 \%$ of the 16 -year-olds and 17 -yearolds, respectively, indicated that they have smoked marijuana.

A look at age of onset reveals that approximately $13 \%$ of the students indicated that they first smoked marijuana at the age of 12 years or younger. For males, the reported youngest age of onset was 2 years. For females, the youngest age of onset was 9 years. The modal age of onset was 12 years.

\section{Perception of Risk}

About $45 \%$ of the students surveyed felt that they do not risk harming themselves if they try marijuana once or twice (Table 2). Roughly half (50\%) of the males felt that they do not risk harming themselves if they try marijuana once or twice; while $41 \%$ of the females felt that they do not risk harming themselves if they try marijuana once or twice. Twenty-six percent of the students surveyed felt there was slight risk of harming themselves if they tried marijuana once or twice. Approximately $7 \%$ of them felt that they would be at great risk if they tried marijuana once or twice. Of those who expressed that it was a great risk to try marijuana once or twice, $2 / 3$ were females while $1 / 3$ were males.

About $31 \%$ of the students surveyed felt that they do not risk harming themselves if they smoke marijuana occasionally. Twenty percent felt there was slight risk of harming themselves if they smoked marijuana occasionally. Approximately $10 \%$ felt that there would be a great risk if they smoked marijuana occasionally. Of those who expressed that it was a great risk to smoke marijuana occasionally, $81 \%$ were females. Twenty-two percent of the respondents did not know the risk associated with smoking marijuana occasionally.

When asked about the risk of smoking marijuana regularly, approximately $30 \%$ of the students felt that they do not risk harming themselves if they smoke marijuana regularly. Thirteen percent felt there was slight risk of harming themselves if they smoked marijuana regularly. Twenty-five percent of the students felt that there would be a great risk if they smoked marijuana regularly. Twenty percent of the respondents did not know the risk associated with smoking marijuana regularly. Of the respondents who did not know the risk associated with smoking marijuana regularly, $61 \%$ were females. 
Table 2 - Perceptions of risk of marijuana use, St. Kitts-Nevis, 2015

\begin{tabular}{lccccc}
\hline \multirow{2}{*}{ Perception of risk } & No risk & \multicolumn{2}{c}{ Slight risk } & Moderate risk & \multicolumn{2}{c}{ Great risk } & \multicolumn{2}{c}{ I don't know } \\
\cline { 2 - 6 } & $\mathbf{n ( \% )}$ & $\mathbf{n ( \% )}$ & $\mathbf{n ( \% )}$ & $\mathbf{n ( \% )}$ & $\mathbf{n ( \% )}$ \\
\hline Risk from using once or twice & $120(44.8)$ & $70(26.1)$ & $16(6.0)$ & $18(6.7)$ & $44(16.4)$ \\
Risk from using occasionally & $82(30.6)$ & $54(20.1)$ & $46(17.2)$ & $26(9.7)$ & $60(22.4)$ \\
Risk from using regularly & $79(29.5)$ & $35(13.1)$ & $32(11.9)$ & $68(25.4)$ & $54(20.1)$ \\
\hline
\end{tabular}

\section{Perception of Benefits}

Data were gathered on students' perception of the benefits associated with smoking marijuana (Table 3). The benefits explored were: for pleasure, social inclusion, helping to cope with emotional difficulties, improving physical well-being (among persons in their age group) and improving academic performance. Over one-third of the students (36\%) were unsure of the extent to which friends admire teenagers who are smoking marijuana. Of the students who were unsure, $45 \%$ were males. Sixteen percent $(16 \%)$ of the students felt that teenagers who smoked marijuana were not at all admired or not admired by their friends. A quarter of the students (25\%) felt that teenagers who smoked marijuana were admired or greatly admired by their friends.

Almost half of the students (49\%) felt that smoking marijuana definitely helps, helps or slightly helps persons their age to cope with their emotional difficulties. One third of the students were unsure of the extent to which smoking marijuana can help their peers to cope with emotional difficulties. About $18 \%$ of the students felt that smoking marijuana definitely does not help, does not help or slightly does not help, persons their age to cope with their emotional difficulties.

With regard to physical well-being, thirty-nine percent (39\%) of the students were unsure as to whether smoking marijuana could help to improve the physical well-being among persons their age group. Approximately $39 \%$ of the students felt that smoking marijuana definitely could not improve, could not improve, or could not slightly improve, physical well-being among their peers. Twenty-seven percent $(27 \%)$ of them felt that smoking marijuana could slightly improve, improve or greatly improve, physical well-being among persons in their age group.

Regarding academic performance, approximately $39 \%$ of the respondents felt that smoking marijuana definitely does not improve, does not improve, or does not slightly improve academic performance. Thirty-five percent (35\%) of the respondents were unsure whether smoking marijuana improves academic performance. Twenty-six percent of the respondents felt that smoking marijuana could slightly improve, improve or definitely improve academic performance.

Of the students surveyed, $45 \%$ were unsure of the extent to which the potential pleasures, or other benefits, provided by smoking marijuana were greater than the potential risks. Twenty-four percent $(24 \%)$ of the respondents felt that the risks were much greater, or greater than, the benefits. Approximately $12 \%$ of the respondents felt that the benefits were greater than, or much greater than, the risks. 
Table 3 - Perceptions of benefits of smoking marijuana, St. Kitts-Nevis, 2015

\begin{tabular}{|c|c|}
\hline Perception of Benefits & n (\%) \\
\hline \multicolumn{2}{|c|}{ Smoking marijuana admired by their friends } \\
\hline Not at all admired & $19(7.2)$ \\
\hline Not admired & $24(9.1)$ \\
\hline Slightly not admired & $25(9.5)$ \\
\hline Unsure & $95(36.0)$ \\
\hline Slightly admired & $35(13.3)$ \\
\hline Admired & $40(15.2)$ \\
\hline Greatly admired & $26(9.8)$ \\
\hline \multicolumn{2}{|c|}{ Potential benefits provided by smoking marijuana greater than risk } \\
\hline Risk much greater than benefits & $36(13.5)$ \\
\hline Risk greater than benefits & $29(10.9)$ \\
\hline Risk slightly greater than benefits & $27(10.2)$ \\
\hline Unsure & $119(44.7)$ \\
\hline Benefits slightly greater than risk & $24(9.0)$ \\
\hline Benefits greater than risk & $15(5.6)$ \\
\hline Benefits much greater than risk & $16(6.0)$ \\
\hline \multicolumn{2}{|l|}{ Help to cope with emotional difficulties } \\
\hline Definitely not helps to cope & $23(8.6)$ \\
\hline Not help to cope & $16(6.0)$ \\
\hline Slightly does no help to cope & $8(3.0)$ \\
\hline Unsure & $89(33.2)$ \\
\hline Help slightly to cope & $56(20.9)$ \\
\hline Helps to cope & $39(14.6)$ \\
\hline Definitely helps to cope & $37(13.8)$ \\
\hline \multicolumn{2}{|c|}{ Improve physical well-being among persons your age } \\
\hline Definitely not improved & $42(15.7)$ \\
\hline Not improved & $49(18.4)$ \\
\hline Slightly not improved & $14(5.2)$ \\
\hline Unsure & $103(38.6)$ \\
\hline Slightly improved & $32(12.0)$ \\
\hline Improved & $17(6.4)$ \\
\hline Greatly improved & $10(3.7)$ \\
\hline \multicolumn{2}{|l|}{ Improve academic performance } \\
\hline Definitely not improved & $56(21.0)$ \\
\hline Not improved & $34(12.7)$ \\
\hline Slightly not improved & $13(4.9)$ \\
\hline Unsure & $94(35.2)$ \\
\hline Slightly improved & $23(8.6)$ \\
\hline Improved & $33(12.4)$ \\
\hline Greatly improved & $14(5.2)$ \\
\hline
\end{tabular}




\section{The association between marijuana smokers/non-smokers and perceived harmfulness}

The mean total perceived harm score for students who have tried marijuana $M=19.93(S D=5.39$, $\mathrm{n}=181$ ) and those who have never tried marijuana $M=25.28, S D=5.64, n=80$ ). A low harm score suggests that students have a low perception of the risks associated with marijuana use; as a result, these students are considered to be at a high risk for using marijuana. For the sample, the mean total perceived harm score is lower for students who have tried marijuana. Analysis was conducted to determine whether there is a statistically significant difference between the mean total perceived harm score for students who have tried marijuana $(M=19.93, S D=5.39, n=181)$ and those who have never tried marijuana $(M=25.28, S D=5.64, n=80)$. An independent samples $t$-test found a statistically significant difference in the harm scores of students who have never tried marijuana and those who have tried it $(\mathrm{t}(259)=-7.27, p=0.000)$.

\section{Regulatory changes and intention to use marijuana}

With regard to intention to use, $10 \%$ of the students indicated that they would use marijuana more often than they do now if it was legal and they were 18 years of age. Thirty percent $(30 \%)$ of the students who have never used marijuana said that they would try it. Chi-square tests were conducted to analyse the association between students' intent to use marijuana, if it were legal, and their perception of the risks as it relates to frequency of marijuana use. To conduct this test, the responses to the hypothetical question, "If you were 18 years of age and marijuana was legal, which of the following would you most likely do?" were placed into two categories: 1) try it or continue to use it, and 2) not use it at all.

The results in Table 4 show that at a $5 \%$ level of significance, there is an association between students' intention to use marijuana, if it were legal and they were 18 years of age, and their perception of risks, if marijuana is smoked once or twice, $\left(\mathrm{c}^{2}{ }_{(\mathrm{df}=3)}=16.832, \mathrm{p}<0.001\right)$; occasionally, $\left(\mathrm{c}^{2}{ }_{(\mathrm{df}=3)}=17.124\right.$, $\mathrm{p}<0.001)$; or regularly, $\left(\mathrm{c}_{(\mathrm{df}=3)}^{2}=14.123, \mathrm{p}<0.001\right)$. Students who perceived that there is high risk associated with using marijuana, tend not to want to use it, even if it was legal. The phi values however indicate that the associations between the intent to use and perception of the risks are small.

Table 4 - Chi-square test results for the association between intention to use marijuana and perception of risks, St. Kitts-Nevis, 2015

\begin{tabular}{lcccc}
\hline $\begin{array}{l}\text { Intention to use marijuana, if regulatory changes } \\
\text { are implemented }\end{array}$ & $\begin{array}{c}\text { Pearson's } \\
\text { chi-square }\end{array}$ & $\begin{array}{c}\text { Asymp. Sig. } \\
\text { (2-sided) }\end{array}$ & df & phi \\
\hline Perception of risk if smoke marijuana once or twice & 16.832 & 0.001 & 3 & 0.285 \\
Perception of risk if used occasionally & 17.124 & 0.001 & 3 & 0.298 \\
Perception of risk if used regularly & 14.123 & 0.001 & 3 & 0.267 \\
\hline
\end{tabular}

Further analysis was conducted to investigate the association between intent to use marijuana, if it were legal, and whether the student had ever tried marijuana. The result shows that there is an association between students' intent to use marijuana, if it were legal, and whether they have used marijuana $\left(\mathrm{c}^{2}{ }_{(\mathrm{df}=1)}=39.964, \mathrm{p}<.001\right)$. Additionally, students who have smoked marijuana are seven times more likely to report that they would continue to use marijuana, if it were legal, than students who have never used marijuana (Odds ratio=7.059, 95\% confidence interval=3.708-13.439). 


\section{DISCUSSION}

This study found that the lifetime prevalence of smoking marijuana, among 15-17 year olds student participants in St. Kits-Nevis is approximately $30 \%$. The survey found that the proportion of males who tried marijuana is higher than that of females. A further look at prevalence showed that the past year prevalence is $24 \%$, and the past month prevalence was $16 \%$. These findings are similar to that of other studies conducted in the English-speaking Caribbean countries.

It was also found that $82 \%$ of the students who have tried marijuana first smoked marijuana when they were 12 years or younger. Of the students who have tried marijuana, most of them first smoked marijuana between the ages of 12 and 14. This is similar to the findings of the CICAD 2013 Secondary School Drug Prevalence St. Kitts-Nevis Survey, ${ }^{8}$ which found that the mean age of onset was 12 years. As indicated previously in the results section, some students indicated that they first smoked marijuana at ages less than 7 years. There is no way to validate such responses, however, it is important to mention that a recent news item ${ }^{13}$ reported that four primary school students, in Nevis, between the ages of 6 and 9 , were found to possess marijuana while on the school premises. Notably, some groups, for example Rastafarians, use marijuana for spiritual enlightenment.

As mentioned in the introduction section of this article, the Organization of American States ${ }^{7}$ points out that the decreasing perception of risk related with marijuana use is one of the factors that explain the increase in marijuana consumption among adolescents. Most of the students surveyed for this current investigation indicated that they were definitely not at any personal risk if they were to smoke marijuana. This finding is similar to that of McGill ${ }^{14}$ who reports that the Monitoring The Future 2012 Teen Drug Use survey, conducted in the United States, found that many teenagers are not aware of the negative effects of marijuana use.

The findings suggest that students generally perceive that there is slight harm associated with smoking marijuana. This finding is somewhat different from the CICAD 2013 Secondary School Drug Prevalence St. Kitts-Nevis Survey, ${ }^{8}$ which found that students, aged 13 to 17 , generally perceive frequent use of marijuana to be very harmful to health. Importantly, this investigation highlights that a relatively high proportion of the students tend to be unsure of the harms associated with smoking marijuana. Hopfer ${ }^{15}$ purports that adolescents are challenged with contrasting claims of the medicinal benefits of using marijuana and the harmfulness of using marijuana. Furthermore, this survey found that students who have never tried marijuana perceive marijuana use to be less harmful than students who have tried marijuana.

A look at the perceived benefits showed that most of the students were unsure of the extent to which the potential pleasures, or other benefits, provided by smoking marijuana were greater than the potential risks. Nearly one in every two students felt that smoking marijuana helps persons their age to cope with their emotional difficulties. A quarter of the students felt that smoking marijuana could improve academic performance. In short, the students generally perceive that there are some benefits of smoking marijuana; however, the majority of the students are unsure of the benefits associated with smoking marijuana. This suggests that students are not knowledgeable about the potential benefits of using marijuana.

When we look at the hypothetical situation if marijuana were legal and the students were 18 years of age, this study found that only 1 out of every 10 students would use it more often that they do now. Further examination showed that there is an association between students' intention to use marijuana, if it were legal and they were 18 years of age, and their perception of the risks. As is expected, students who perceived that there is high risk associated with using marijuana, tend not to want to use it, even if it was legal. This supports an argument for preventive programmes for youths on the risks associated with using marijuana. In addition, the result showed students who 
have smoked marijuana are seven times more likely to continue to use marijuana, if it were legal, than students who have never used marijuana. This further supports an argument for educating the youths on the risks associated with using marijuana. Hopfer ${ }^{15}$ suggests that prevention approaches used to educate adolescents should address perceptions of the safety of using marijuana and claims of beneficial benefits. Hopfer warns that, if marijuana is legal, adolescents may see an increase in open use and advocators for marijuana use, even among family members; as a result, there will be the need for a substantial increase in efforts to educate adolescents on marijuana. Warner Staff ${ }^{16}$ reports that after the legalization of recreational marijuana in Colorado, United States of America, the second public service campaign, aimed at keeping teenagers away from marijuana, was careful not to vilify marijuana. Instead, efforts were made to ensure that the campaign provided teenagers with information that would assist them in making an informed decision.

This study found that students are not well educated on the potential risks, harms and benefits associated with using marijuana. Interestingly, the CICAD 2013 Secondary School Drug Prevalence Survey, ${ }^{8}$ conducted in St. Kitts-Nevis, reported that $72 \%$ of the students indicated that they have not attended school activities geared towards preventing drug use. It is therefore recommended that suitable educational and prevention programmes be developed to inform students on the risks, harms, and benefits of using marijuana. It is highly recommended that these programmes should commence in the primary schools.

Similar to national alcohol campaigns, for example, the St. Kitts-Nevis National Council on Drug Abuse Prevention ${ }^{17}$ "Enjoy 'youself' you hear but drink responsibly" 67-second animation produced to reduce alcohol-related harm, there is a need for marijuana awareness campaigns. Drug education videos can be a good discussion starter for viewers; ${ }^{18}$ however, she warns that the preachiness of drug education videos can turn off the viewers.

Given that the questionnaire was limited in the potential harms, potential benefits and ways of using marijuana, it is recommended that the questionnaire be expanded and administered to a wider age range of adolescents. More so, owing to the regional and national discussions on the decriminalization of marijuana, it is recommended that similar investigations be conducted among the adult population. The current Prime Minister of St. Vincent, Dr Ralph Gonsalves has called for more studies on marijuana. ${ }^{19} \mathrm{It}$ is therefore recommended that further investigations seek to investigate the social, legal, economic and health issues associated with marijuana use, to guide the development of suitable national policies.

This survey was limited to 15 to 17 year old students enrolled in public secondary schools. Similar surveys conducted in St. Kitts-Nevis, for example the CICAD survey, ${ }^{8}$ gather data from a wider age range of students and students in private schools. In addition, this investigation was limited to a convenient sample of only 3 secondary schools, on the island of St. Kitts after obtaining permission and support from the administration of these schools. The perception of students in Nevis was not examined.

Although the questionnaire was piloted to ensure that the language was clear and the questions were explicit, there was no way to validate some of the responses given by the students. Efforts were made to assure the students of confidentiality and the importance for them to be truthful in their responses; however, given the nature of the topic, some students may not be truthful in their responses.

The questionnaire concentrated on gathering data on students' perception of the harms and benefits of smoking marijuana. The questionnaire did not take into consideration other means of using marijuana, such as in marijuana tea, marijuana cookies and vapourized marijuana, which have the potential of higher potencies. Additionally, the potential harms and potential benefits of using marijuana that were evaluated in the questionnaire were limited. 


\section{CONCLUSION}

The findings of this investigation suggest that most students perceive that there is no personal harm associated with marijuana use. Students perceive that there are some benefits associated with marijuana use however they are not sure whether the potential benefits are greater than the potential risks. This study also found that a relatively high proportion of students were unsure of the harms and benefits associated with marijuana use. Furthermore, students who have tried marijuana have a low perception of the risks associated with marijuana use and are seven times more likely to continue to use marijuana if it were legal and they were 18 years of age.

\section{REFERENCES}

1. Caribbean-Marijuana-Regional consultation on marijuana gets underway this week. CANA News [Internet] (2016, June 13). Caribbean Search.

2. Ministry of Justice, Government of Jamaica. Fact Sheet - Dangerous Drug (Amendment) Act 2015 [online] [cited 2016 May 28]. Available from: http://moj.gov.jm/sites/files/Dangerous $\% 20$ Drugs\%20Amendment\%20Act\%202015\%20Fact\%20Sheet_0.pdf

3. Telesur. The Cannabis Movement in St. Lucia is Demanding Radical Change. [online] [cited 2016 May 28]. Available from: http://www.telesurtv.net/english/news/The-Cannabis-Movement-in-St.Lucia-Is-Demanding-Radical-Change-20160425-0030.html

4. Bobb K. The Case of Marijuana Decriminalization. [online] NOW Grenada, 2015 July [cited 2016 May 28]. Available from: http://nowgrenada.com/2015/07/the-case-for-marijuana-decriminalization/

5. ZIZ News. Is it time to decriminalize marijuana? ZIZ National Broadcasting Cooperation of St. Kitts-Nevis [online] [cited 2016 May 31] 2014 March 26. Available from: http://zizonline.com/isit-time-to-decriminalize-marijuana/

6. National Council on Drug Abuse Prevention. National Discussion on Decriminalization of Marijuana in St. Kitts and Nevis. 2014, March. [unpublished]

7. Organization of American States - OAS. The drug problem in the americas: Studies Legal and regulatory alternatives. 2013. Available from: http://www.cicad.oas.org/drogas/elinforme/ informeDrogas2013/alternativasLegales_ENG.pdf

8. Inter-American Drug Abuse Control Commission-CICAD. Secondary Schools Drug Prevalence Survey- St. Kitts and Nevis. Washington(US): CICAD; 2013.

9. Inter-American Drug Abuse Control Commission - CICAD. Comparative analysis of student drug use in Caribbean Countries: Antigua and Barbuda, Barbados, Dominica, Grenada, Guyana, Haiti, Jamaica, St. Kitts and Nevis, St. Lucia, St. Vincent and the Grenadines, Trinidad and Tobago, and Suriname: A Report on Student drug use in 12 Caribbean Countries. 2011. Available from: http://ncda.org.jm/images/pdf/researchday/studentdrug.pdf

10. Johnston LD, O'Malley PM, Miech RA, Bachman JG, Schulenberg JE. Monitoring the Future national results on drug use: 1975-2013: Overview, Key Findings on Adolescent Drug Use. Ann Arbor (US): Institute for Social Research, The University of Michigan; 2014. Available from http:// monitoringthefuture.org//pubs/monographs/mtf-overview2013.pdf

11. Benthin A, Slovic P, Severson H. A psychometric study of adolescent risk perception. Journal of adolescence. 1993;16(2):153-68.

12. Magar E, Phillips L, Hosie J. Self-regulation and risk-taking. Personality and Individual Differences. 2008;45(2):153-9.

13. Hewlett L. Child Caught Selling Weed at Primary School [Internet]. WINNFM.com. 2016 [31 May 2016]. Available from: http://www.winnfm.com/news/local/16698-child- caught-selling-weed-atprimary-school. 
14. McGill N. Annual survey shows many teens brush off risks of marijuana use. Nation's Health . [Academic Search Premier]. (2013, Feb);43(1):7

15. Hopfer C. Implications of Marijuana Legalization for Adolescent Substance Use. Substance Abuse. 2014;35(4):331-5.

16. Warner Staff, K. How is a pro-pot state like Colorado keeping teens away from marijuana? Christian Science Monitor [Academic Search Premier]. (2015, Aug 20).

17. St. Kitts-Nevis National Council on Drug Abuse Prevention. "Enjoy 'youself' you hear but drink responsibly". [Internet] 2015. [cited 24 June 2016]. Available from: https://www.facebook.com/StKitts-Nevis-National-Council-on-Drug-Abuse-Prevention- Secretariat-1499515607009493/videos

18. Glantz S. L-evated: the blunt truth. School Library Journal [Internet]. (1998, June);44(6):79. Available from: https://www.slj.com/?

19. Caribbean-Marijuana-St. Vincent PM wants more studies on marijuana. CANA News [Caribbean Search]. (2016, Jan 27). 


\section{NOTES}

\section{CONTRIBUTION OF AUTHORITY}

Study design: Gray-Phillip G, Brands B.

Data collect: Gray-Phillip G.

Data analysis and interpretation: Gray-Phillip G, Brands B.

Discussion of the results: Gray-Phillip G, Brands B.

Writing and / or critical review of content: Gray-Phillip G, Brands B.

Review and final approval of the final version: Gray-Phillip G.

\section{ACKNOWLEDGMENTS}

Many thanks to the Organization of American States through Inter-American Drug Abuse Control Commission, the Government of Canada, the Centre of Addition and Mental Health, Akwatu Khenti, Dr. Hayley Hamilton, Dr. Bruna Brands, Dr. Robert Mann, Dr. Carla Ventura, Ms. Katherine Lo, Principals, teachers and guidance counsellors who assisted in organizing students for the data gathering, the students who completed the questionnaire, the students who participated in the pilot survey, the Director of the St Kitts-Nevis National Drug Council, Tevin Phillip for data entry and Ivor Phillip for his encouragement and support.

\section{ETHICS COMMITTEE IN RESEARCH}

Ethical approval was sought and granted by the Centre of Addiction and Mental Health Research Ethics Board, Toronto, Canada. Additionally, ethical approval was sought and granted by the St. KittsNevis Chief Medical Officer, who has the responsibility of evaluating research proposals in the field of health and granting ethical approval.

\section{CONFLICT OF INTEREST}

There is no conflict of interest.

\section{HISTORICAL}

Received: September 25, 2018.

Approved: May 20, 2019.

\section{CORRESPONDENCE AUTHOR}

Gaile Gray-Phillip

gailephillip@gmail.com 